\title{
IDENTIFICATION OF EMPLOYABILITY SKILLS AMONG TECHNICAL AND VOCATIONAL EDUCATION MASTER STUDENT IN UNIVERSITY TUN HUSSEIN ONN MALAYSIA (UTHM): A CASE STUDY
}

\author{
Mohamad Rasidi Pairan ${ }^{*}$, Shahrul Azmir Osman², Nur Hazirah Noh@Seth ${ }^{1}$, Ahmad Nabil Md Nasir 1 , \\ Mohd Rustam Mohd Rameli ${ }^{1}$, Hanifah Jambari ${ }^{1}$, Nurul Aini Mohd Ahyan ${ }^{1}$, Muhammad Nasir Nasrul ${ }^{3}$ \\ ${ }^{1}$ School of Education, Faculty of Social Sciences and Humanities, Universiti Teknologi Malaysia, \\ 81310 Skudai, Johor, Malaysia \\ ${ }^{2}$ Faculty of Mechanical and Manufacturing Engineering, Universiti Tun Hussein Onn Malaysia, 86400 \\ Parit Raja, Johor, Malaysia \\ ${ }^{3}$ Faculty of Technical Education and Vocational, Universiti Tun Hussein Onn Malaysia, 86400 Parit \\ Raja, Johor, Malaysia \\ *rasidi@utm.my
}

\begin{abstract}
The factor that is most commonly discussed related to employability rate among masters' graduates is the lack of employability skills, set by the employers apart of the academic qualifications. This study is conducted to identify the level of employability skills among final year student of Master in Technical and Vocational Education, Universiti Tun Hussein Onn Malaysia (UTHM) and to identify the employability skills set by the employers. Quantitative research design using survey opted where the samples focus on 108 masters' students and 42 employers selected randomly among educational institutions. The questionnaires were distributed to the respondents using simple random sampling and the data was analysed using descriptive statistical and statistical inference. The results recorded average level of employability skills among the students, with the mean score of 3.025. It can be concluded that the lecturers play an important role to enhance the students' employability skills. However, the students must be responsible for enhancing their employability skills so that their employability rate could be enhanced to grab the working opportunity upon graduation.
\end{abstract}

Keywords: Employability Skills, Employability Rate

\section{INTRODUCTION}

Higher education institutions in Malaysia has always been trying to widen the teaching and research program in line with one of the government's projections, which is to increase trained and skilled human resources in order to fulfil the market's needs and requirements in various industries. The academic programme offered by each institution should be able to produce not only high-quality graduates but also graduates with employability skills needed by the employers. Low employability rate among higher education graduates is not because of the lack of vacancies, but because of the mismatch skills defined by a mismatch between the skills required by the industry, and the skills possessed by technical graduates. The issue of marketability among graduates of Technical and Vocational Education is an issue that has been a concern lately. Most of the students who follow this program are those who aspire to become higher educators. Although the program is offered towards becoming an educator, it is not a guarantee for graduates to continue to be absorbed in education. There are several factors that influence employers to take this SPTV graduates to work. The previous research found that, the proficiency and mastery of soft skills have become the main requirement for modern workers nowadays (Callan, 2003). Nonetheless, oral, non-verbal, and verbal communication skills are the essential skills employers need (Suleiman et al., 2006). In addition, the differences skills exist between the students and the skills required by the employer should also be known. Perhaps because of these differences, it would affect the opportunity to candidate to seize jobs. This is support by Omain et al. (2007), he reported that, the differences skills existed among institute graduates with the skills required by industry have been the cause of graduates not getting a place in the industry. The reason of why employer find 
employees from abroad is because the local Graduates who do not meet employer standards (Nordin, 2003). Therefore, this study is conducted to identify the types of abilities available to students and the types of abilities that the employer's priority.

\section{OBJECTIVES}

The lack of the skills benchmarked by the employers is among the reasons why the employers prefer to outsource the workers from elsewhere. Employability skills education and lifelong learning skills should be accentuated as these are the keys throughout the teaching and learning process (Noor \& Sukor, 2005). The lack of employability skills, social skills, as well as competitive job market is the weaknesses highlighted by the employers (Radin Sohadi et al., 2006). Furthermore, employability skills are also the skills needed in the industry to create balanced highly skilled workers along with outstanding academic qualifications (Emat, 2005). This statement supported by Juhdi and Shaharudin Yunus (2007), as they highlighted that the graduates failed to secure any job because of the lack of employability skills.

\section{METHODOLOGY}

This study opted fordescriptive statistical research and statistical inference through a survey to identify the skills required by the employers with the employability skills attained by the graduates. The analysis was then conducted to obtain the mismatch skills required by the employers in order to fulfil the requirement by higher education institutions. The research instrument was built based on generic skills model outlined by the Ministry of Higher Education, Malaysia, and was modified and improved to suit the objectives of this study. Hence, this study focuses on seven elements of employability skills which are:

1. Communication skill

2. Teamwork skill

3. Lifelong learning skill

4. Problem-solving skill

5. Leadership skill

6. Technical skill

7. Ethical skill

In this study, the questionnaire survey form was used to gather the information on the employment rate among Technical and Vocational Education masters' graduates, employability skills attained by the graduates, and the primary elements of employability skills required by the employers. The data gathered was then analysed using the Statistical Package for Social Sciences (SPSS) Version 17.0. The location selected for the sampling was Universiti Tun Hussein Onn Malaysia and other higher education institutions such as Kolej Kemahiran Tinggi Mara (KKTM), Pusat Latihan Teknologi Tinggi, and Institut Kemahiran Mara (IKM). In this study, there are two different populations selected, namely the student of UTHM and the employers. 4 Likert-scale questionnaire was opted in this study.

\section{RESULTS AND DISCUSSION}

The elements of employability skills are dominantly attained by Master in Technical and Vocational Education students, based on the highest mean are as shown in Table 1. Based on Table 1, the ethical skill is among the element of employability skills placed first in the hierarchal order of Masters in Technical and Vocational Education at UTHM. This is reflected by the highest mean value for interpretation evaluation with 3.352 , while the value of standard deviation is moderately low with 0.357. Teamwork skill placed second in the hierarchal order with the mean score of 3.240 and standard deviation of 0.307 , lifelong learning skill placed third with the mean score of 3.181 ; and the standard deviation of 0.352 , followed by problem-solving skills with the mean score of 2.980 and standard deviation of 0.353 . Technical skills recorded the mean score of 2.90 with a standard deviation of 0.370 followed by leadership skills with the mean score of 2.858 and standard deviation of 0.364 . Communication skills placed last in the hierarchal score with the mean score of 2.666, recorded together with 0.297 of standard deviation.

Table 1. Dominant elements of employability skills among the students 
The Turkish Online Journal of Design, Art and Communication - TOJDAC

ISSN: 2146-5193, September 2018 Special Edition, p.862-865

\begin{tabular}{|c|c|c|c|c|}
\hline $\begin{array}{c}\text { Employability } \\
\text { Skills Elements }\end{array}$ & $\begin{array}{c}\text { Mean } \\
\text { Score }\end{array}$ & $\begin{array}{c}\text { Interpretation } \\
\text { Evaluation }\end{array}$ & $\begin{array}{c}\text { Standard } \\
\text { Deviation }\end{array}$ & $\begin{array}{c}\text { Hierarchal } \\
\text { Order }\end{array}$ \\
\hline Ethical skill & 3.352 & High & 0.357 & 1 \\
\hline Teamwork skill & 3.240 & High & 0.307 & 2 \\
\hline Lifelong learning skill & 3.181 & High & 0.352 & 3 \\
\hline Problem solving skill & 2.980 & Medium & 0.353 & 4 \\
\hline Technical skill & 2.900 & Medium & 0.370 & 5 \\
\hline Leadership skill & 2.858 & Medium & 0.364 & 6 \\
\hline Communication skill & 2.666 & Medium & 0.297 & 7 \\
\hline Average & 3.025 & High & 0.343 & - \\
\hline Total respondents & & 108 & & \\
\hline
\end{tabular}

Based on this analysis, the ethical, teamwork, and lifelong learning skills are the elements of employability skills with high mean scores showing that all the respondents have successfully mastered these three elements. This may be because of the curriculum for Masters in Technical and Vocational Education program which incorporate a lot of ethical values, group work assignments, and lifelong learning activities. From the results, it was also observed that problem-solving skill, technical skill, leadership skill, and communication skill are the elements of employability skills with average mastery level. These are the elements lacking in the curriculum to be improved in the near future. Furthermore, all elements of employability skills recorded the value of standard deviation of less than 1, corresponding to the level of understanding among the respondents are similar and the distribution is normal.

The elements of employability skills prioritised by the employers in their institutions are listed in the hierarchal order in Table 2.

Table 2. Dominant elements of employability skills prioritised by the employees

\begin{tabular}{|c|c|c|c|c|}
\hline $\begin{array}{c}\text { Employability } \\
\text { Skills Elements }\end{array}$ & $\begin{array}{c}\text { Mean } \\
\text { Score }\end{array}$ & $\begin{array}{c}\text { Interpretation } \\
\text { Evaluation }\end{array}$ & $\begin{array}{c}\text { Standard } \\
\text { Deviation }\end{array}$ & $\begin{array}{c}\text { Hierarchal } \\
\text { Order }\end{array}$ \\
\hline Ethical skill & 3.649 & High & 0.256 & 1 \\
\hline Teamwork skill & 3.670 & High & 0.283 & 2 \\
\hline Lifelong learning skill & 3.458 & High & 0.234 & 5 \\
\hline Problem-solving skill & 3.393 & High & 0.317 & 7 \\
\hline Technical skill & 3.649 & High & 0.256 & 3 \\
\hline Leadership skill & 3.455 & High & 0.280 & 6 \\
\hline Communication skill & 3.530 & High & 0.248 & 4 \\
\hline Average & 3.556 & High & 0.266 & - \\
\hline Total respondents & & 42 & & \\
\hline
\end{tabular}

Based on Table 2, the employability skill prioritised by the employers in fulfilling the requirement of the higher institution is ethical skill, which recorded the mean score of 3.649 with a standard deviation of 0.256 . The second most prioritised element is teamwork skill with the mean score of 3.670 and 
standard deviation of 0.283 , followed by the technical skill which recorded the mean score of 3.649 and standard deviation of 0.256 , and communication skill which recorded the mean score of 3.530 and standard deviation of 0.248 . In addition, lifelong learning skill and leadership skill, both recorded the mean score of 3.458 and 3.455 respectively and standard deviation of 0.234 and 0.280 respectively, while the lowest element of employability skill set by the employers is problem-solving skill with the mean score of 3.393 with 0.317 of standard deviation.

\section{CONCLUSION}

From the analysis, the data shows that all interpretation of element in employability skills recorded high mean score. All elements are essential to be acquired by the students who will be the potential employee at higher institutions. Furthermore, higher institutions are keen on employing potential candidates who have acquired all the elements of the employability skills which have been studied intensively in this research.

\section{REFERENCES}

Callan, V. J. (2003). Generic skills: Understanding vocational education and training teacher and student attitudes. National Centre for Vocational Education Research.

Emat, Y. (2005). Pendidikan teknik dan vokasional di Malaysia. IBS Buku Sdn. Bhd.

Juhdi, N., \& Shaharudin Yunus, A. J. (2007). A study on employability skills of university graduates. The Business Wallpaper, 2(1), 1-6.

Noor, N. M., \& Sukor, N. M. A. (2005). Penerapan kemahiran employability di institusi latihan perindustrian Pasir Gudang, Johor Bahru. Universiti Teknologi Malaysia.

Nordin, M. Y. (2003). Isu dan cabaran dalam penyediaan tenaga kerja dalam era perubahan teknologi dan globalisasi. In National Seminar on Vocational Education and Training.

Omain, S. Z., Jusoh, A., Low, H. H., Mohd Salleh, N., \& Mohd Yatim, S. (2007). Penentuan kemahiran yang bersesuaian untuk pelajar Sarjana Muda Pengurusan Teknologi. Universiti Teknologi Malaysia. Radin Sohadi, R. U., Abu, M. N., Razally, W., Badushah, J., Buyong, A.H, Hashim, H., \& Tamsi, N. A. (2006). Modul pembangunan kemahiran insaniah (soft skills) untuk Institusi Pengajian Tinggi Malaysia. Universiti Putra Malaysia.

Suleiman, E. S., Baharun, R., \& Simpol, M. S. (2006). Changing skills required by the industries: Perception of what makes business graduates employable. Master thesis, Universiti Teknologi Malaysia. 